\title{
Application of Learning Softball Using Modified Glove and Ball for Developing Basic Movement Skills Throwing and Catching for High School Students
}

\author{
Mudjihartono Mudjihartono, Wahyudianto Wahyudianto, Agus Gumilar ${ }^{*}$ \\ Departemen Pendidikan Olahraga Dan Kesehatan, Fakultas Pendidikan Olahraga dan Kesehatan \\ Universitas Pendidikan Indonesia \\ Bandung, Indonesia \\ *gumilaragus27@upi.edu
}

\begin{abstract}
This study aims to determine how the application of softball learning using equipment glove and ball modification can be carried out in physical education learning can perform basic motion throwing and catching skills for student. The method used is classroom action research with the research design used is the kurtlewin model with participant's high school students. Assessment instruments using observation sheets. The results of this study experienced an increase in catching and throwing skills can be seen from the presentation of the value of students who have reached the minimum completeness criteria the results of catching skills from the initial test to the first cycle increased by $43.24 \%$ in the second cycle increased by $32.44 \%$ and the results of throwing skills were each the actions experienced an increase from the initial test to the first cycle increased by $51.35 \%$ in the second cycle increased by $13.51 \%$. The results of the analysis showed that the application of softball learning using modified of glove and ball gave an improvement to the basic motion skills of throwing and catching high school students.
\end{abstract}

Keywords-softball; modification; glove; ball; catching; throwing

\section{INTRODUCTION}

Facilities and infrastructure which is a tool that has a very important role for the success and smoothness of an educational process, facilities that are absolutely fulfilled to provide convenience in conducting a teaching and learning activity. Softball learning usually uses facilities and infrastructure such as softball balls, glove, batt, helmet, helmet catcher, leg guard, chest / body protector, mask as a tool for delivering material to students and as equipment for students carrying out motion tasks in softball learning. In the odd semester of the 2016/2017 school year the author carried out Field Experience Program activities at SMAN 7 Bandung. Based on the results of the teaching experience that the author has done in the physical education learning process at the school does not have such learning media infrastructure facilities therefore softball learning in the school has never been taught to students, resulting in students' ability to know basic skills and softball playing skills in survive (defensive) and attack (offensive) is very lacking therefore the role of the teacher in dealing with the limitations of learning infrastructure facilities by modifying media and learning is very necessary so that softball learning can be implemented in physical education learning.

So the limitations of learning media are not an obstacle for a penjas teacher not to deliver softball learning material to students. There are various ways to get around the limitations of media in softball learning by modifying learning media [1]. The lack of physical education facilities and equipment possessed by schools, requires physical education teachers to be more creative in empowering and optimizing the use of existing facilities and equipment in accordance with the conditions of students and their schools. School pages, parks, empty rooms, trenches, schools and so on that are in an environment that can be engineered and utilized to optimize learning in accordance with the desired goals. The research emphasizes the modification of how to use it, but there is also a modification of the equipment to capture the ball using equipment that is safer, such as soft and smaller balls, so that they can be easily captured with both hands [2].

Another research about modification of softball is Argo ball [3]. This research modifies the game of dynamic rules because the teacher modifies the rules of the game from simple and simple games to more forms of play tactical and complex physically. Making games more complex physically or mentally challenges students to acquire new skills and apply critical analysis to their game play tactics. The relevance of the research carried out in relation to the study both examined modifications but the study modified the rules of the game more complex physically or mentally challenging students to acquire new skills and apply critical analysis to their game play tactics. The author uses equipment that is modified more to the defense method does not teach how to attack.

Based on the opinion above the learning process of softball does not always have to use standard media but can use other media in the school environment, thus the authors anticipate the limitations of learning media by modifying glove and ball 
media so that softball learning can be done at school and students can do throwing and catching skills survive softball learning.

\section{METHOD}

\section{A. Participant}

Research subjects have a very important role in a study, because the subject of research is something that will be known information or as a target in a study. Research subjects can be objects or humans. In this study the research subjects were students of class X MIPA I SMA Negeri 7 Bandung with 37 students consisting of 17 male students and 20 female students.

\section{B. Procedures}

For the method used in this research is the method of classroom action research, classroom action research is a study that applies a particular action to solve problems that occur in the classroom using rules according to the research methodology carried out in several cycles according to the desired needs. The purpose of class research is to improve the quality of learning and help empower teachers to solve learning problems that occur in a classroom. The plan prepared is the implementation of learning skills in capturing and throwing in defense of softball learning giving the task of moving the situation to survive using a ball made of tennis balls coated with foam, affixed with a cloth followed by a pattern and glove made of cloth gloves attached to fastener / magic tape / patch. In carrying out actions on classroom action research conducted in two meetings at each cycle.

The research design on the basic reference class action research method refers to the Kurt Lewin model, as stated by Kusumah and Dwitagama [4], namely "The Kurt Lewin model is the main reference or basis for the existence of various other classroom action research models. Kurt Lewin's model consists of 4 components, namely a) planning (planning), b) actions (acting), c) observation (observing), and d) reflection (reflecting)".

\section{Instruments}

This study focuses on one aspect, namely the psychomotor aspect of capturing and throwing skills in surviving softball learning, its assessment as long as students do the defensive game using the capture assessment observation sheet carried out as long as students perform learning performance.

\section{Results AND Discussion}

In Softball errors is a part of the game, can catch errors or throw errors and so on. Basic attitude or movement must be mastered perfectly, because this basic motion determines the next movement. The more perfectly mastered the basic motion, the more proficient you will be in capturing or throwing movements even if it is difficult to catch or throw in softball games [5]. The application of learning media modification is an effort made by researchers to deal with the limitations of softball learning media using glove and ball so that softball learning can be carried out at school. Together with that, researchers indirectly conduct softball learning at school and students do capturing and throwing skills in surviving softball learning so that students get successful experience is the most fundamental essence in providing motion assignments in physical education. This must also be accompanied by the creativity of the teacher in composing motion assignments that gradually adjust to the students' abilities.

The results of student grades during the pre-research and research took place, namely from the initial test, the first cycle, and the second cycle in carrying out capturing and throwing skills in defense of softball learning as follows:

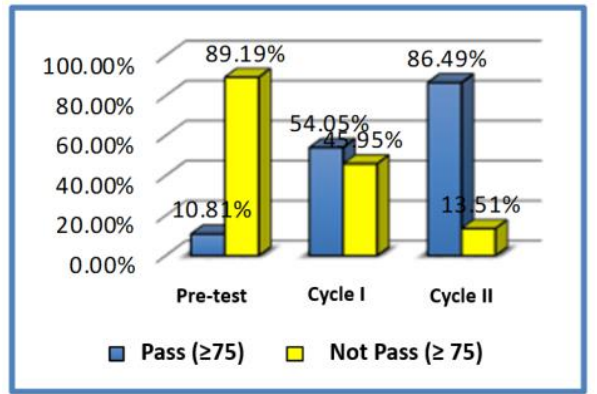

Fig. 1. Comparison of classical completeness capturing during the research process.

From that data each action experienced an increase from the initial test to the first cycle increased by $43.24 \%$ in the second cycle experienced an increase of $32.44 \%$ the increase in capturing learning outcomes during the study took place presented in the graphic form below:

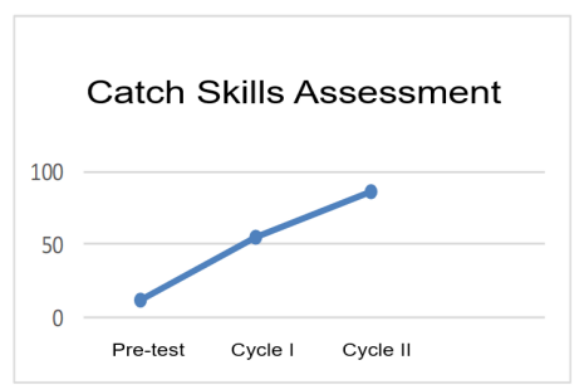

Fig. 2. Increased classical accomplishment captured during research.

Next is the result of analysis and assessment of throwing skills:

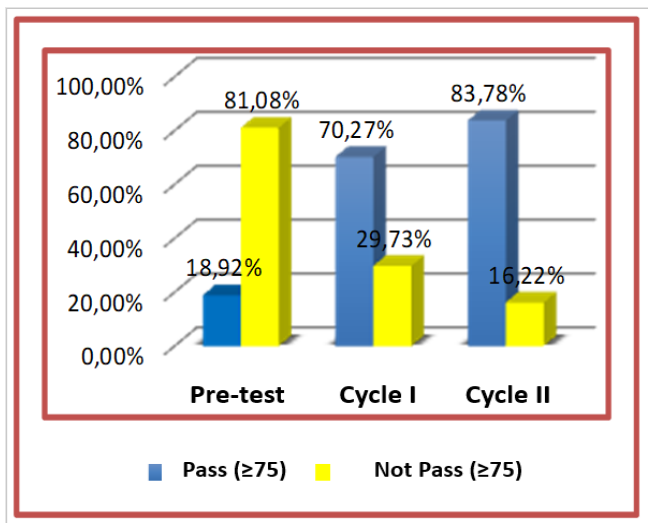

Fig. 3. Comparison of classical completeness throws during the research process. 
From that data each action experienced an increase from the initial test to the first cycle increased by $51.35 \%$ in the second cycle experienced an increase of $13.51 \%$ the increase in the results of throwing learning during the study took place presented in the graphic form below:

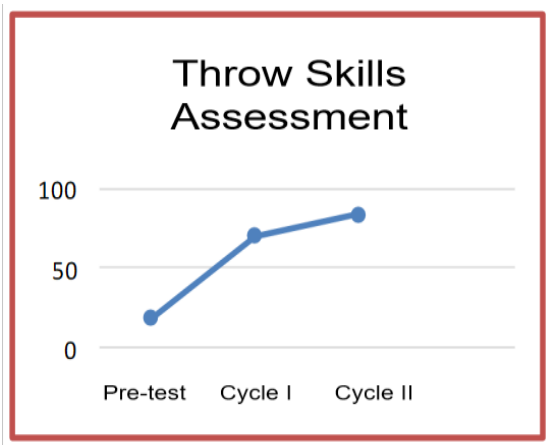

Fig. 4. Increased classical completeness throws during the research process.

Learning outcomes in learning to capture and throw skills in surviving softball learning using the implementation of media modification learning capture and throw skills in defense of softball learning are as follows:

- The results of the learning process using media modification of capturing and throwing skills learning in surviving softball learning are said to be successful, if $\geq 75 \%$ of the total students reach a score range of 75 100 .

- The results of the learning process using media modification of capturing and throwing skills learning in surviving softball learning are said to have not been successful, if $<75 \%$ of the total students have not reached the 75 - 100 value range.

In cycle II the skill of capturing students based on classical completeness criteria has reached $86.49 \%$ or $\geq 75 \%$ of the total students reaching a value range of 80-93. And in the second cycle the throwing skills of students based on classical completeness criteria had reached $83.78 \%$ or $\geq 75 \%$ of the total students reached a value range of $80-90$.

\section{CONCLUSION}

Modification of softball learning media in the form of modified glove and ball as safe as possible for students to anticipate the implementation of learning not to catch and throw in surviving softball learning in students of class $\mathrm{X}$ MIPA I SMA 7 Bandung. During the learning process the skills of students experience a significant increase during the study taking place both from the use of learning media modifications and the factors of student talent, environmental factors, learning that the teacher provides and others. Researchers can reflect on each lesson so that they experience an increase in how researchers teach in delivering material.

\section{REFERENCES}

[1] Y. Bahagia and Mujianto, Fasilitas perlenglapan penjas. Bandung: Universita Pendidikan Indonesia, 2010.

[2] D.L. Gallahue, J.C. Ozmun and J. Goodway, Understanding Motor Development: Infants, Children, Adolescents, Adults. New York: McGraw-Hill, 2012.

[3] J.R. Todorovich, J. P. Fox, S. Ryan and S.W. Todorovich, "Argoball: A dynamic-rules game for teaching striking-and-fielding game tactics," Journal of Physical Education, Recreation \& Dance, vol. 79, no. 5, pp. 26-41, 2008.

[4] W. Kusumah and D. Dwitagama, Mengenal Penelitian Tindakan Kelas Edisi: 2. Jakarta: PT Indeks, 2011

[5] Suparlan, Permainan Softball. Bandung: Universitas Pendidikan Indonesia, 2008. 